\title{
Discrepancy of Real Tariffs with INA-CBG'S for Dengue Haemorrhagic Fever Patients in a Hospital in Sidoarjo 2019
}

\author{
Marthy Meliana Ariyanti Jalmav ${ }^{1,2}$, Amelia Lorensia ${ }^{2}$, Suyanto ${ }^{3}$, Achmad Syahrani1 ${ }^{4}$ \\ ${ }^{1}$ Undergraduate Study of Pharmacy, Sekolah Tinggi Ilmu Kesehatan Rumah Sakit Anwar Medika, Sidoarjo, \\ East Java, Indonesia \\ ${ }^{1,2,3}$ Faculty of Pharmacy, Universitas Surabaya, East Java, Indonesia \\ ${ }^{4}$ Faculty of Pharmacy, Universitas Airlangga, East Java, Indonesia \\ marthy.stikesrsam@gmail.com,sekretariat@stikesrsanwarmedika.ac.id
}

\begin{abstract}
Dengue Hemorrhagic Fever (DHF) patients in Indonesia reached 129,650 cases with a death toll of 1,071 people in 2015. DHF puts an economic burden on the community and government. This study aims to determine the difference in real cost tariffs and INA $C B G$ 's for DHF in a hospital in Sidoarjo, East Java. This cross-sectional study applied a descriptive design, conducted from January to December 2019. The data in this study consisted of characteristic data and differences in real hospital tariffs and INA CBG tariffs for DHF in the hospital treatment room. 625 hospitalized cases were included in this study. This hospital underwent a deficit (loss) of 30\% from the difference between the total INA $C B G$ 's package tariffs and the total real hospital tariffs in 2019. There is a negative difference between the real hospital tariffs and the tariffs according to INA CBG's in the treatment of dengue fever in a hospital in Sidoarjo which produces losses for the hospital.
\end{abstract}

Keywords: $D H F$, insurance, $J K N, I N A-C B G$ 's

\section{Introduction}

The World Health Organization (2011) states that the world's population is estimated at 2.5-3 billion at risk of contracting dengue haemorrhagic fever (DHF), especially those living in urban areas in tropical and subtropical countries (Organization, 2011). Dengue infections worldwide reach 50 million every year. In Southeast Asia, it is estimated that there are as many as 100 million cases of dengue fever and 500,000 cases of dengue that require hospital treatment and around 25,000 deaths in Southeast Asia for dengue disease reach 5\% annually (Bedouch et al., 2012).

By the Strategic Plan of the Ministry of Health of the Republic of Indonesia, strategic targets in Health Development for 2015-2019 include reducing morbidity due to infectious diseases, by increasing the percentage of districts/cities with Dengue Haemorrhagic Fever (DBD) morbidity rate of $\leq 49$ per 100,000 populations (Moll et al., 2011). It is targeted that in 2017 it will be at least 64\%, in 2018 it will be at least $66 \%$ and in 2019 it is expected that at least $68 \%$ of districts/cities will have a dengue fever rate of $\leq 49$ per 100,000 populations. Dengue haemorrhagic fever is still a world public health problem, especially in tropical and subtropical regions, including Indonesia as one of the dengue-endemic countries (Haryanto et al., 2014). Since the first time DHF cases were reported in Indonesia in 1968 in Jakarta and Surabaya, the DHF morbidity rate has shown an increasing trend from year to year and the area of its spread has become wider in almost all districts/cities in Indonesia (Noisakran and Perng, 2008). However, the death rate due to dengue in the last decade has been reduced to below $1 \%$.

The high incidence of dengue fever can cause an increment in the health budget, especially the cost of drugs and medical consumables during hospitalization. The government budget is limited, so it is necessary to choose the use of drugs by taking into account quality 
and cost control, as well as the study of pharmacological aspects in the selection and use of drugs effectively and efficiently in analyzing drug costs (Shander et al., 2010; Syakur, 2018).

The medical expenses incurred in the JKN era are matters that need to be considered because the determination of real hospital cost tariffs is designed so that the hospital does not suffer losses for any actions given by the hospital to patients which include operational costs, maintenance, development, and improvement of service quality (Suaya et al., 2009; Syakur et al., 2020a) which exists. The real costs also include hospital service tariffs such as hospital services, medical services, therapeutic services, laboratory tests, anaesthesia, use of medical materials and devices, so that it is hoped that a balance can occur between an increase in real costs and an increase in services received by patients and the patient's ability to pay for these costs.

The role of the pharmaceutical industry in the health sector is one of the most important pieces for society because the pharmaceutical industry is a partner of the government to improve public health (Syakur et al., 2020b). With this JKN program, if it is not managed properly, it will create losses to the Pharmaceutical Industry due to low costs and low margins, besides that, it can also cause losses to hospitals if drug administration is not effective and efficient. Hence the role of pharmacists in the selection of effective and efficient therapies as well as rational treatment is needed because the form of procurement of drugs and medical devices, especially pharmaceuticals, refers to the three main aspects of health insurance, namely easy access (accessibility), affordable prices and logical use of drugs (rational). Drug procurement in the JKN era is one of the most important components including medical expenses so that to achieve the objectives of this government program, the availability of drugs is of the utmost importance for the program's success (Shander et al., 2010; Suaya et al., 2009)

In this research, the average real cost of direct medical costs was calculated, so that the goal of this study was to ascertain whether there was a difference from the real costs incurred by the Hospital for Dengue Fever Patients for JKN-BPJS participants, with the real costs received by the hospital INA CBG's JKN-BPJS package tariffs.

\section{Research Method}

This research was conducted with a cross-sectional study design utilizing a descriptive design. Data collection was carried out retrospectively in class I, II, and III care rooms and in the case-mix room of a hospital in Sidoarjo from January to December 2019 with the number of research subjects using total sampling. The population was all DHF patients who were treated at a hospital in Sidoarjo with funding using the BPJS from January to December 2019. The research subjects were part of the population that met the inclusion criteria, namely dengue fever patients with complete medical record data, undergoing treatment in a hospital in Sidoarjo, using BPJS coverage. Patients who did not meet the inclusion criteria were excluded from the study. The materials used in the study were medical records of patients diagnosed with dengue fever.

Hospital tariffs are the total costs incurred by patients while undergoing treatment at the hospital in the form of administrative costs, accommodation, nursing care, transfusion measures, doctor examinations, supporting examinations, medicines, and medical devices as well as consumable medical items.

The data in this study are data obtained from characteristic data and data on disparities between real tariffs and INA CBG tariffs. Demographic data in this study are age, gender, class of care, and length of stay (LOS). All data were analyzed using SPSS version 23 and presented in tabular form. 


\section{Discussion}

There were 625 inpatient cases of dengue fever patients who were included in the study with data on the characteristics of research subjects in Table 4 which shows that the number of male subjects was higher than women, namely 345 (55.2\%) while women were $280(44.8 \%)$. This condition was observed in the mild dengue fever as many as 405 cases $(64.8 \%)$, followed by severe dengue fever as many as 201 cases $(32.16 \%)$ and moderate dengue fever as many as 19 cases (3.04\%).

The total real tariff for one year for dengue fever cases is Rp. 2,737,682,647. This figure is obtained from 625 hospitalized cases, most of which consist of 277 young adults (aged 14-28 years) so it can be estimated that each young adult is the average cost of Rp. $1,213,340,949$ per year. Throughout 2019, a hospital in Sidoarjo received a negative value of Rp. $821,193,747(-30 \%)$ of the difference between the total INA CBG package tariff and the total real tariff spent by the hospital, as shown in Table 5.

The incidence of this deficit is classified based on the severity of the disease, class of care, and length of stay as presented in Table 3, it can be observed that the highest deficit incidence is $76 \%$ in patients with mild dengue fever and class 3 patients. the deficit occurred at treatment over 5 days.

The average cost during hospitalization consists of expenses for non-surgical procedures, consultations, experts, nursing, support, radiology, laboratories, accommodation rooms, medicines, medical devices, consumable medical items, and equipment rental which are detailed in Table 6.

Table 4. Characteristics of Research Subjects

\begin{tabular}{llr}
\hline \multicolumn{2}{c}{ Characteristics } & $\begin{array}{c}\text { Inpatient Cases } \\
(\mathbf{n = 6 2 5})\end{array}$ \\
\hline Gender & Women & 280 \\
\multirow{4}{*}{ Age } & Men & 345 \\
& $<$ 14 Years & 187 \\
& 14-28 Years & 277 \\
& 29-43 Years & 95 \\
DF severity & $\geq 44$ Years & 66 \\
& Mild & 405 \\
& Moderate & 19 \\
Class of Care & Severe & 201 \\
& 1 & 93 \\
\multirow{4}{*}{ LOS } & 2 & 252 \\
& 3 & 280 \\
Complication & Yes & 257 \\
& No & 368 \\
& & 293 \\
& & 332 \\
\hline
\end{tabular}


Table 5. Difference between Total Hospital Real Tariffs and INA CBG's Real Tariffs

\begin{tabular}{cccc}
\hline $\begin{array}{c}\text { Total Real } \\
\text { Hospital Tariffs }\end{array}$ & $\begin{array}{c}\text { Total Tariffs INA } \\
\text { CBG's }\end{array}$ & $\begin{array}{c}\text { Total Tariffs } \\
\text { Difference }\end{array}$ & $\begin{array}{c}\text { Percentage } \\
\text { Difference }\end{array}$ \\
\hline IDR & IDR & -IDR & $-30 \%$ \\
2.737 .682 .647 & 1.916 .488 .900 & 821.193 .747 & \\
\hline
\end{tabular}

Table 6. Incidence of Deficits According to Severity, Class of Care and Length of Stay

\begin{tabular}{lccccc}
\hline & Deficit & n (\%) & No Deficit & n (\%) & Total \\
\hline Severity & & & & & \\
Mild DHF & 395 & $76 \%$ & 10 & $10 \%$ & 405 \\
Moderate DHF & 17 & $3 \%$ & 2 & $2 \%$ & 19 \\
Severe DHF & 108 & $21 \%$ & 93 & $89 \%$ & 201 \\
Class of Care & & & & & \\
Class 1 & 75 & $14 \%$ & 18 & $17 \%$ & 93 \\
Class 2 & 217 & $42 \%$ & 35 & $33 \%$ & 252 \\
Class 3 & 228 & $44 \%$ & 52 & $50 \%$ & 280 \\
Length of Stay & & & & & \\
$<$ 5 Days & 190 & $37 \%$ & 67 & $64 \%$ & 257 \\
$\geq$ 5 Days & 330 & $63 \%$ & 38 & $36 \%$ & 368 \\
& & & & & \\
\hline
\end{tabular}

Table 6. Details of Hospital Tariffs

\begin{tabular}{lcc}
\hline \multicolumn{1}{c}{ Type of Fee } & \multicolumn{2}{c}{ Average } \\
\hline Non-Surgical Procedures & IDR & 2.562 .645 \\
Consultation & IDR & 76.444 \\
Expert & IDR & 6.192 \\
Nursing & IDR & 69.790 \\
Support & IDR & 3.754 \\
Radiology & IDR & 5.528 \\
Laboratorium & IDR & 72.646 \\
Accommodation Room & IDR & 227.240 \\
Drug & IDR & 65.973 \\
Medical Devices & IDR & 50.121 \\
Consumable Medical & & \\
Materials & IDR & 16.702 \\
Rental Tools & IDR & 6.219 \\
\hline
\end{tabular}




\section{Discussion}

Most of the cases of dengue fever who were hospitalized in a hospital in Sidoarjo were men (55.2\%), this is similar to the study at Buleleng Hospital in 2013, where DHF patients were mostly male (51\%). When compared with women which were only $49 \%$. However, it is different from the research conducted by Wijayanti, et al, which states that most of the Jamkesmas in patients are women with a percentage of 56.02\%. The highest age range for dengue fever patients is the age group 14-27 years (44.32\%). This is different from the research of Wijayanti, et al which states that the highest age group of inpatients is 40-49 years old $(16.87 \%)$ which is also different from the research conducted by Djati, et al, which states that the age group $<12$ years is the highest age group for dengue fever because it has weaker humoral immune system function compared to the cellular immune system and the immune system possessed by the adult age group. Data from Infodatin (Ministry of Health, 2016) shows the incidence of DHF occurs mostly in adulthood, although the incidence of DHF does not depend on age. This result is also in accordance with the distribution data in Indonesia for 2012-2015 that based on gender, the number of men and women is not too different.

Length of stay was assessed by extracting the duration of hospital stay measured in hours or days. In this study, the highest length of stay (LOS) for DHF patients was> 5 days (63\%) compared to $<5$ days (37\%). The average length of stay for DHF patients was 5.3 days. The results of other studies stated that in 8 countries in America and Asia, the average illness period of DHF patients was 11 days, with an average fever duration of 6 days (Banggai et al., 2019; Noisakran and Perng, 2008).

From Table 2 it is discovered that there is a difference of $30 \%$ between the real tariff and the INA CBG tariff. This is in accordance with research from Suratni, et al, which states that in billing patient payments with National Health Insurance (JKN) for cases of dengue fever, the hospital casemix team reports that $60 \%$ of the bill exceeds INA CBG's tariffs. This research, particularly that they both find differences between the application of real tariffs and package tariffs (Katmini and Syakur, 2020; Nopianto et al., 2012). Meanwhile, according to (Nopianto et al., 2012) the factors that influence the difference in tariffs include the inflation component of hospital costs, government policies, third party payments (insurance), and health workers themselves.

Table 3 explicates that the incidence of deficits occurs in a long length of stay (LOS) (> 5 days), namely $63 \%$. This can be caused by secondary diagnoses that boost the degree of severity so that it can add to the diagnosis code and procedures of the secondary diagnosis can increase INA-CBGs tariffs (Polyzos et al., 2013; Syakur et al,, 2020b). This is not per the statement from the BPJS as the organizer of JKN in Indonesia which claims that at the beginning of the implementation of the INA CBG's package, around 94 hospitals claimed to have a surplus with INA CBG's financing costs compared to the old tariffs, such as the Islamic Hospital (RSI) in Surabaya. INA CBG tariffs received by the hospital which are low compared to the real tariffs issued by the hospital will result in the hospital experiencing losses.

The longer the patient is treated, the higher the cost will be because the length of stay is calculated at the real tariff per day, whereas in INA CBGs the standard tariffs have been decided according to the actual diagnostic and procedure codes. (Alhamda and Barlian, 2019) states that by reducing patient length of stay, the cost for CBG can be reduced (Zhuo et al, 2013). This is supported by the opinion of Alhamda and Barlian (2009) who saw from the medical aspect that with a longer length of stay, the quality of medical performance is not good because the patient recovers longer. When viewed from an 
economic point of view for real tariffs, the longer the stay, the higher the fees paid by the payer and received by the hospital, whereas this does not apply to INA CBGs tariffs which are not affected by the length of stay. So that if the hospital can regulate the provision of health services in terms of length of stay effectively and efficiently, it will increase the chance of a good difference (surplus) between the real tariffs and INA CBG's tariffs.

In Table 4, it can be seen that the largest cost component is for non-surgical procedures that have been adjusted to the clinical pathway at the hospital. This is following the statement in the Jamkesmas Implementation Guidelines for the Centre for Health Financing and Insurance, the Ministry of Health (2013 and 2016) which states that the cost of medical services/service fee is determined by the Hospital Director at a maximum of $44 \%$ of the cost of health services provided. The medical services/service fee include fees for service providers in the framework of observation, diagnosis, treatment, medical action, treatment, consultation, visit, and/or other medical services, as well as for implementing service administration.

\section{Conclusion}

There is a negative difference between the real hospital tariffs and the INA CBG tariffs in cases of dengue fever in a private hospital in Sidoarjo, causing losses for the hospital. Additional analytical research is needed to analyse the cost of treating dengue fever patients with the JKN system by the BPJS.

\section{References}

Alhamda S., Barlian E. (2019) Strategy $3 \mathrm{M}$ plus to reduce incidence disease dengue haemorrhagic fever in Public Health Centre (PHC) Tigo Baleh Bukittinggi West Sumatra-Indonesia, IOP Conference Series: Earth and Environmental Science, IOP Publishing. pp. 012001.

Banggai C.E., Lisdawati V., Suliati S., Kusumowardhani D., Firmansyah I., Montain M.M. (2019) Association between hemoconcentration and longer hospitalization day of dengue patients.

Bedouch P., Marra C.A., FitzGerald J.M., Lynd L.D., Sadatsafavi M. (2012) Trends in asthma-related direct medical costs from 2002 to 2007 in British Columbia, Canada: a population based-cohort study. PloS one 7:e50949.

Haryanto B., Purba W.H., Sonny P.W. (2014) Dengue Hemorrhagic Fever Vulnerability to Climate in Indonesia: Assessment, Projection and Mapping, International Society for Environmental Epidemiology Conference. pp. 24-28.

Katmini K., Syakur A. (2020) Pola Asuh Orang Tua Otoriter dengan Kemampuan Activities Of Daily Living (ADL) pada Anak Retardasi Mental Usia 6-12 Tahun di SLB Yayasan Putra Asih Kediri Tahun 2018. Briliant: Jurnal Riset dan Konseptual 5:163-171.

Moll F.L., Powell J.T., Fraedrich G., Verzini F., Haulon S., Waltham M., van Herwaarden J.A., Holt P.J., van Keulen J.W., Rantner B. (2011) Management of abdominal aortic aneurysms clinical practice guidelines of the European society for vascular surgery. European Journal of Vascular and Endovascular Surgery 41:S1-S58.

Noisakran S., Perng G.C. (2008) Alternate hypothesis on the pathogenesis of dengue hemorrhagic fever (DHF)/dengue shock syndrome (DSS) in dengue virus infection. Experimental Biology and Medicine 233:401-408. 
Nopianto H., Riyanto B., Ariani M.D. (2012) Faktor-faktor yang berpengaruh terhadap lama rawat inap pada pasien demam berdarah dengue di rsup dr kariadi semarang, Fakultas Kedokteran.

Organization W.H. (2011) Comprehensive guideline for prevention and control of dengue and dengue haemorrhagic fever.

Polyzos N., Karanikas H., Thireos E., Kastanioti C., Kontodimopoulos N. (2013) Reforming reimbursement of public hospitals in Greece during the economic crisis: implementation of a DRG system. Health policy 109:14-22.

Shander A., Hofmann A., Ozawa S., Theusinger O.M., Gombotz H., Spahn D.R. (2010) Activity-based costs of blood transfusions in surgical patients at four hospitals. Transfusion 50:753-765.

Suaya J.A., Shepard D.S., Siqueira J.B., Martelli C.T., Lum L.C., Tan L.H., Kongsin S., Jiamton S., Garrido F., Montoya R. (2009) Cost of dengue cases in eight countries in the Americas and Asia: a prospective study. The American journal of tropical medicine and hygiene 80:846-855.

Syakur A. (2018) Hubungan Kualitas Pelayanan Terhadap Kepuasan Mahasiswa dan Loyalitas Mahasiswa Ditinjau dari Model Pembelajaran di Akademi Farmasi Surabaya. 2018 8:100-108.

Syakur A., Susilo T.A.B., Wike W., Ahmadi R. (2020a) Sustainability of Communication, Organizational Culture, Cooperation, Trust and Leadership Style for Lecturer Commitments in Higher Education. Budapest International Research and Critics Institute (BIRCI-Journal): Humanities and Social Sciences 3:1325-1335.

Syakur A., Zainuddin H., Hasan M.A. (2020b) Needs Analysis English For Specific Purposes (ESP) For Vocational Pharmacy Students. 2020 3:724-733.

Zhuo X., Zhang P., Hoerger T.J. (2013) Lifetime direct medical costs of treating type 2 diabetes and diabetic complications. American journal of preventive medicine 45:253-261. 